\title{
Successful closure of a very large secundum atrial septal defect with the Occlutech Figulla ${ }^{\circledR}$ device
}

Skuteczne zamknięcie bardzo dużego ubytku w przegrodzie międzyprzedsionkowej typu II za pomocą urządzenia Occlutech Figulla ${ }^{\circledast}$

\author{
Abdurrahman Tasal, Ahmet Bacaksiz, Ercan Erdogan, Osman Sonmez \\ Department of Cardiology, Faculty of Medicine, BezmiÂlem Foundation University, Istanbul, Turkey
}

Postep Kardiol Inter 2012; 8, 4 (30): 347-350

DOI: $10.5114 /$ pwki.2012.31918

\begin{abstract}
Atrial septal defect (ASD) is one of the most common adult congenital heart diseases. It is characterized by a defect in the interatrial septum allowing pulmonary venous return from the left atrium to pass directly to the right atrium. It can result in pulmonary hypertension, congestive heart failure and cerebrovascular accident, so elective closure is recommended for all ASDs with evidence of right ventricular overload or with a clinically significant left-to-right shunt. Treatment methods include surgical and percutaneous closure. Transcatheter device closure is the method of choice in most centres nowadays. The rate of complications and length of hospital stay are lower compared to surgical closure. This technique can be performed successfully for a wide range of defects. Very large defects with inadequate rims could decrease the procedural success. The Occlutech Figulla ASD Flex Occluder is a new percutaneous closure device with some advantages such as higher flexibility, minimized amount of material implanted, and absence of the left atrial clamp in order to reduce trauma risk and clot formation on the left atrial disc. We think that these unique features could increase the procedural success rate. We report a patient with a very large defect who underwent transcatheter device closure using the Occlutech Figulla ${ }^{\circledR}$ device.
\end{abstract}

Key words: atrial septal defect, transcatheter closure, Occlutech Figulla ${ }^{\circledR}$ device, adult congenital heart disease

\section{Streszczenie}

Ubytek w przegrodzie międzyprzedsionkowej (atrial septal defect - ASD) jest jedną z najczęstszych wrodzonych wad serca u dorosłych. Umożliwia on powrót krwi żylnej z żył płucnych przez lewy przedsionek bezpośrednio do prawego przedsionka. Sytuacja ta może prowadzić do wystąpienia nadciśnienia płucnego, zastoinowej niewydolności serca oraz incydentów mózgowo-naczyniowych. W związku z tym zaleca się planowe zamknięcie wszystkich ASD z cechami przeciążenia prawej komory lub z istotnym klinicznie przeciekiem lewo-prawym. Metody terapeutyczne obejmują operację i zamknięcie przezskórne. Obecnie w większości ośrodków preferuje się zamknięcie przezcewnikowe. Wiąże się ono z mniejszą częstością występowania powikłań i krótszym pobytem w szpitalu w porównaniu z zamknięciem chirurgicznym. Techniki przezskórne można skutecznie zastosować w wielu rodzajach ubytków. Skuteczność zabiegu może być jednak zmniejszona w przypadku bardzo dużych ubytków z niewłaściwymi brzegami. Occlutech Figulla ASD Flex Occluder ${ }^{\circledR}$ jest nowym narzędziem do przezskórnego zamykania ubytków, który ma pewne zalety, takie jak większa giętkość, minimalna ilość wszczepianego materiału obcego oraz brak zacisku po stronie lewego przedsionka w celu zmniejszania ryzyka urazu oraz formowania się skrzeplin na dysku w lewym przedsionku. Autorzy uważają, że te unikalne cechy umożliwią zwiększenie skuteczności zabiegów przezskórnych. W pracy przedstawiono pacjenta z bardzo dużym ubytkiem, który przeszedł zabieg przezskórnego zamknięcia ubytku z zastosowaniem urządzenia Occlutech Figulla ${ }^{\circledR}$.

Stowa kluczowe: ubytek w przegrodzie międzyprzedsionkowej, zamknięcie przezcewnikowe, urządzenie Occlutech Figulla®, wada wrodzona serca $u$ dorostych

\section{Introduction}

Transcatheter closure of secundum atrial septal defect (ASD) is an effective and alternative therapy to surgery with similar results for suitable lesions [1-3]. We report a very large defect treated successfully with the Occlutech Figulla ${ }^{\circledR}$ ASD Flex Occluder.

Corresponding author/Adres do korespondencji:

Ahmet Bacaksiz MD, Department of Cardiology, Faculty of Medicine, BezmiÂlem Foundation University, Vatan Street, 34093 Fatih/Istanbul, Turkey, tel.: + 90 (212) 45317 00, fax: + 90 (212) 62175 80, e-mail: ahmetbacaxiz@mynet.com

Praca wptynęła: 1.08.2012, przyjęta do druku: 30.10.2012. 


\section{Case report}

A 36-year-old man was admitted to our outpatient clinic with complaints of shortness of breath on exertion and palpitation. On examination, he had wide and fixed split of the second heart sound with a soft ejection systolic murmur at the left upper parasternal border. Transthoracic echocardiography revealed a large ASD measuring $39 \mathrm{~mm}$ with evidence of mild pulmonary arterial hypertension and mildly dilated right heart chambers with normal biventricular systolic function.

The patient preferred a nonsurgical mode of treatment so we planned to perform transcatheter closure. Transoesophageal echocardiography (TEE) in the catheterization laboratory measured $43 \mathrm{~mm}$ ASD without the anterosuperior (AS) rim (Fig. $1 \mathrm{~A}$ ). The distance between the two rims in the short axis was $43 \mathrm{~mm}$ and in the longitudinal bicaval view was $41 \mathrm{~mm}$ (Fig. 1 B). The patient underwent initial right heart catheterization. Calculated Qp/Qs was $1.9: 1$ and pulmonary artery pressure was $47 / 22 \mathrm{~mm} \mathrm{Hg}$ (mean: $29 \mathrm{~mm} \mathrm{Hg}$ ). After $5000 \mathrm{IU}$ of intravenous heparin, the ASD crossed with a 6 Fr multipurpose catheter (MultiPurpose $A-1^{\circledR}$, Cordis, Miami, Florida, USA) and an Amplatz extra stiff wire 0.035 " (Cook, Bloomington, IN, USA) was positioned into the left upper pulmonary vein (UPV). The multipurpose catheter was removed. It was decided to implant a $40 \mathrm{~mm}$ Occlutech Figulla ${ }^{\circledR}$ ASD Flex Occluder (Occlutech, $\mathrm{GmbH}$, Germany). The device was loaded using the standard technique in a $14 \mathrm{Fr}$ delivery sheath. The device was inserted and deployed under fluoroscopic and TEE guidance. We applied left UPV technique as described previously [4]. In brief, the left atrial (LA) disk of the device was initially placed in the left UPV (Fig. $1 \mathrm{C}$ ). The right atrial (RA) disk was delivered following the fall of the LA disk into its place and the shunt was completely occluded. Device placement was checked with TEE, which showed no residual shunt and unobstructed flow across both the atrioventricular valves and systemic and pulmonary veins (Fig. $1 \mathrm{D}$ ). The patient tolerated the procedure well. He was advised to continue oral combination of aspirin and clopidogrel for 3 months. He remained asymptomatic after the procedure. The position of the device was confirmed before discharge.

\section{Discussion}

Percutaneous transcatheter closure is the preferred strategy for the management of patients with ASD nowadays. Defect size and presence of adequate rims are the major determinants of procedural success. Evidence from device therapy in patients with a very large (exceeding $35 \mathrm{~mm}$ ) defect is limited. We have reported a patient with a very large $(43 \mathrm{~mm})$ defect treated successfully with the Occlutech Figulla ${ }^{\circledR}$.

Isolated secundum ASD is the second most common congenital heart disease in adults [1]. The patient can present with a variety of clinical symptoms including right ven- tricular failure, pulmonary hypertension, atrial arrhythmias, and paradoxical embolism, although they often remain asymptomatic until early adulthood [2]. Percutaneous transcatheter closure of the defect is recommended in symptomatic patients and in the presence of marked left-toright shunt, left ventricular dysfunction, right ventricular dilatation, and paradoxical embolism [3]. Surgical closure is indicated if the defect size exceeds $38 \mathrm{~mm}$ or in the case of inadequate defect rims other than the anterosuperior rim. Compared with surgical repair, transcatheter closure is safer and physiological, so it has become an effective and alternative therapy to operation in most patients [5].

An adequate posteroinferior rim is essential for successful transcatheter closure of the defect, whereas an anterosuperior rim of $5 \mathrm{~mm}$ is also needed for stable positioning of the device [6]. Deficiency of the anterosuperior rim and the size of the defect are the most important factors that contribute to the difficulty involved in transcatheter closure [5]. Although closure of small to moderate-sized defects is feasible and technically easy, device closure of large defects still remains a challenge [4]. A large defect, especially associated with deficient rims (measuring less than $5 \mathrm{~mm}$ from the defect to the atrial wall), may decrease the success rate of the procedure. Some authors have reported successful complete closure rates in adult patients with a defect larger than $20 \mathrm{~mm}$ but there is limited evidence in patients with very large defects $[4,6,7]$. To the best of our knowledge, this is the first report of complete percutaneous closure with the Occlutech Figulla ${ }^{\circledR}$ in a very large ASD.

There are several available techniques that have been reported to be used to overcome such difficulties during closure of large secundum defects including left and right upper pulmonary vein techniques, as well as dilatorassisted and balloon-assisted techniques $[4,6]$. The right upper pulmonary vein method is the most frequently applied technique for device deployment in large defects. In our patient, the device was delivered using the left upper pulmonary vein technique because it is easier to perform and feasible without any balloon or dilator assistance.

The Amplatzer Septal Occluder (AGA Medical Corp., Golden Valley, Minnesota, USA) and the Occlutech Figulla ASD Flex Occluder (Occlutech, GmbH, Germany) are two devices available to close large defects. Both devices can be used with similar efficacy and safety [8]. The latter device has lower nitinol content and is free of a central hub in the left atrial disc, which make the device more flexible, contribute to better deployment and minimize the risk for thrombus formation following implantation [9]. The patient reported here had a very large defect without an adequate anterosuperior rim, making deployment of the device difficult.

Several manoeuvres might be required which might increase the procedure related risks. A flexible device with- 

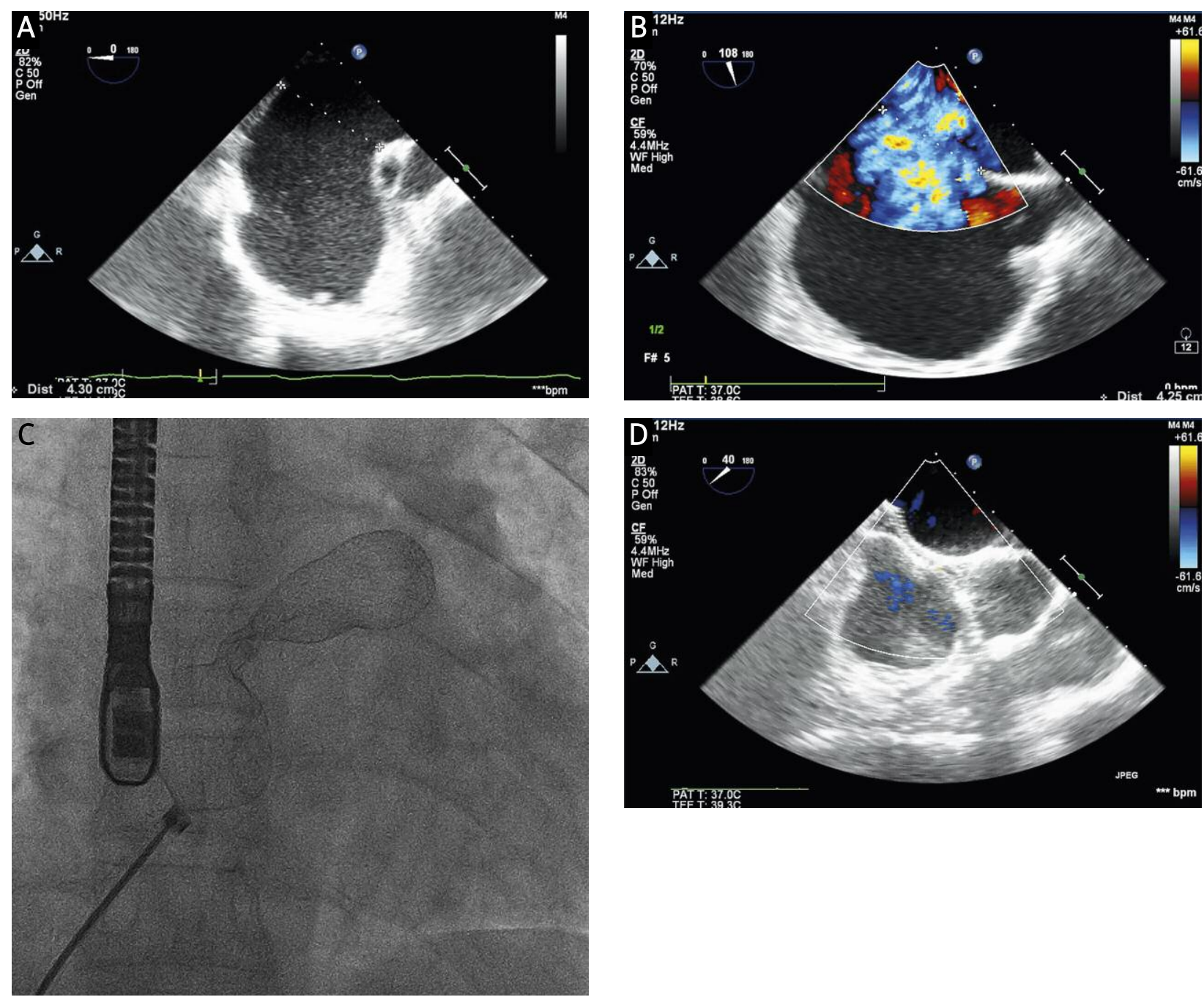

Fig. 1. A - Transoesophageal echocardiography. Modified short axis view. Very large atrial septal defect with inadequate anterosuperior rim. B - Transoesophageal echocardiography. Modified bicaval view. Demonstration of very large atrial septal defect with colour Doppler. C - Angiogram. Left upper pulmonary vein technique used for deployment of the device. D - Transoesophageal echocardiography. Short axis view. Control of residual defect after release of the Occlutech Figulla ${ }^{\circledR}$ device

Ryc. 1. A - Echokardiografia przezprzetykowa. Zmodyfikowana projekcja w osi krótkiej. Bardzo duży ubytek w przegrodzie międzyprzedsionkowej z niewłaściwym brzegiem przednio-górnym. B - Echokardiografia przezprzetykowa. Zmodyfikowana projekcja dwujamowa. Uwidocznienie bardzo dużego ubytku w przegrodzie międzyprzedsionkowej za pomoca kolorowego dopplera. C - Angiogram. Technika lewej żyły płucnej górnej stosowana do uwolnienia urządzenia. D - Echokardiografia przezprzetykowa. Projekcja w osi krótkiej. Badanie kontrolne pod kątem przecieku rezydualnego po wszczepieniu urządzenia Occlutech Figulla ${ }^{\circledR}$

out a central hub in the left atrial disk provides easy manipulation and could be used confidently in these kinds of defects. So, we preferred the Occlutech Figulla. In conclusion, the Occlutech Figulla is a new and alternative percutaneous closure device for patients with a very large atrial septal defect.

\section{Acknowledgments}

Published with the written consent of the patient. No external funding and no competing interests declared.
The authors would like to thank Prof. Omer Goktekin for all his input and guidance on this case report.

\section{References}

1. McMahon CJ, Feltes TF, Fraley JK, et al. Natural history of growth of secundum atrial septal defects and implications for transcatheter closure. Heart 2002; 87: 256-259.

2. Ilkay E, Kaçmaz F, Ozeke O, et al. The efficiency and safety of percutaneous closure of secundum atrial septal defects with the Occlutech Figulla device: initial clinical experience. Turk Kardiyol Dern Ars 2010; 38: 189-193. 
3. Baumgartner H, Bonhoeffer P, De Groot NM, et al. ESC Guidelines for the management of grown-up congenital heart disease (new version 2010). Eur Heart J 2010; 31: 2915-2957.

4. Park SJ, Kim NK, Kim JO, et al. Morphologic characteristics and relating factors to the need of technical modification in transcatheter closure of large atrial septal defect $(>/=25 \mathrm{~mm})$. Korean Circ J 2010; 40: 191-196.

5. Durongpisitkul K, Tang NL, Soongswang J, et al. Predictors of successful transcatheter closure of atrial septal defect by cardiac magnetic resonance imaging. Pediatr Cardiol 2004; 25: 124-130.

6. Fu YC, Cao QL, Hijazi ZM. Device closure of large atrial septal defects: technical considerations. J Cardiovasc Med (Hagerstown) 2007; 8: 30-33.

7. Varma C, Benson LN, Silversides C, et al. Outcomes and alternative techniques for device closure of the large secundum atrial septal defect. Catheter Cardiovasc Interv 2004; 61: 131-139.

8. Pac A, Polat TB, Çetin II, et al. Figulla ASD occluder versus Amplatzer Septal Occluder: a comparative study on validation of a novel device for percutaneous closure of atrial septal defects. J Interv Cardiol 2009; 22: 489-495.

9. Halabi A, Hijazi ZM. A new device to close secundum atrial septal defects: first clinical use to close multiple defects in a child. Catheter Cardiovasc Interv 2008; 71: 853-856. 